\title{
The Pathogenicity of Aeromonas salmonicida (Griffin) in Sea and Brackish Waters
}

\author{
By MARY SCOTT \\ Northumbrian River Authority, Newcastle upon Tyne
}

(Accepted for publication 9 August 1967 )

\section{SUMMARY}

The experimental pathogenesis of Aeromonas salmonicida for the sea trout (Salmo trutta) and the brown trout (Salmo fario) in sea and brackish waters was examined by contact between infected and healthy fishes. Sea trout and brown trout both acquired infection by contact with infected $S$. fario at salinity values from $2.54 \%$ to $3.31 \%(w / w)$ when water temperatures ranged from $5.6^{\circ}$ to $14.5^{\circ}$. The species differed in their resistance to infection. About $90 \%$ of the sea trout became infected and died within 7 days, developing superficial lesions typical of the disease. The brown trout appeared to be more resistant, about $75 \%$ developing and dying from an atypical form of the disease.

\section{INTRODUCTION}

Aeromonas salmonicida is the causal agent of furunculosis, a specific infective disease of fish. Mackie et al. (1930) stated that the genus Salmo, which contains both freshwater and migratory species of fish, was most frequently affected. In their Final Report, the Furunculosis Committee stated that the degree of susceptibility varied between different species, salmon (Salmo salar), sea trout or salmon trout (Salmo trutta), and American brook trout (Salmo or Salvelinus fontinalis) were very susceptible, whilst the rainbow trout (Salmo irideus) was more resistant. Investigation of the dissemination of the disease was made under the direction of the Furunculosis Committee between the years 1928 and 1934. As a result of these investigations Mackie et al. (1935) reported that furunculosis was acquired exclusively in fresh water and that migratory Salmonidae became infected after they had left the sea. These widely held views (McCraw, 1952) are based mainly on field observations. McCraw (1952) stated that 'it is difficult to conceive the propagation of furunculosis among salmon or other fish in the sea as it has been shown that the specific organism survives for only a short time in sea water'. Field observations reported by Mackie et al. (1930, 1933, 1935) indicated that active spread of furunculosis did not occur to any extent where the volume of water per single fish was great. Furthermore, temperature conditions in the sea would generally be unfavourable to the development and spread of the disease. However, although it may be argued that the volume of water per single fish is great in the ocean, prevailing conditions such as temperature and volume of water in certain tidal areas may be comparable with those upstream in fresh water. Migratory Salmonidae tend to congregate in pools in tidal water for considerable periods before moving upstream (Jones, 1959), such a condition predisposing transmission of infection. Smith (1962) stated that investigations (unpublished) had shown that the viability of Aeromonas salmonicida in sea 
water was not negligible, and that bacteriological examination of smolts for the organism revealed that these fish might be infected. Therefore $A$. salmonicida may not only pass from one adult host to another, it may also pass from an adult host to a juvenile host and survive a period in the sea, with the consequence that at least part of the returning migrants are infected before they reach fresh water. Thus, if the longevity of A. salmonicida is comparable in sea water, brackish water and fresh river water, it would appear that furunculosis might also be acquired in tidal waters. There is an obvious need for detailed information about the pathogenesis of $A$. salmonicida in saline waters. The following is an account of such an investigation planned as a set of small-scale epizootological experiments in which transmission of infection in sea and brackish water was attempted between sea trout ( $S$. trutta) and also land-locked trout ( $S$. fario) by contact with brown trout which had died from furunculosis.

\section{METHOD}

Aeromonas salmonicida. Two strains of $A$. salmonicida, morphologically and biochemically identical but isolated from different sources, were used for the experiments. Strain 5 was isolated from a brown trout, strain 7 from a salmon smolt. Both cultures were examined for purity, consistency of biochemical activity and pathogenicity at regular intervals during the period of experimentation.

Culture of bacteria from fish. Fish were seared on the undersurface before opening and sampling. Bacterial specimens for plating were taken with a platinum wire loop from heart-blood, spleen, liver, kidney and intestine. Several loopfuls were taken from each organ; inoculum tissue was macerated with a sterile scalpel. Spreading of the inoculum on solid Blood Agar Base No. 2 (Oxoid) in Petri dishes was done by using a sterile glass spreader. The plates were incubated aerobically at $20^{\circ}$ for at least $48 \mathrm{hr}$. The brown pigment which is generally accepted to be characteristic of $A$. salmonicida developed in the agar in this time.

Suspensions of Aeromonas salmonicida. Ten ml. of sterile physiological saline were added in small portions to a well-grown $48 \mathrm{hr}$ slope culture of the organism, the growth being emulsified with the aid of a wire loop. The suspension was then decanted and allowed to stand for $30 \mathrm{~min}$. until bacterial clumps and fragments of agar had sedimented. The suspension was then standardized to tube 2 of Brown's opacity standards (Mackie \& McCartney's Handbook, I960).

Experimental infection tanks. Three polythene-lined galvanized tanks enclosed by movable wire-netting covers were set up under natural conditions as experimental tanks. Brown trout inoculated intramuscularly with Aeromonas salmonicida were housed in one tank, capacity $\mathrm{I} 6.25 \mathrm{cu}$.ft., $\left(0.46 \mathrm{~m} .^{3}\right)$ which was open to sunlight and provided with a regulated supply of well-water at constant temperature $\left(4^{\circ} 4^{\circ}\right)$. The other tanks were placed in a shaded position, a smaller tank, capacity $16 \cdot 25 \mathrm{cu} . \mathrm{ft}$., which contained sea water being set above the level of the larger tank, capacity $24 \cdot \mathrm{I}$ cu.ft. $\left(0.68 \mathrm{~m}^{3}\right)$ which contained fresh well-water. The lower tank was used as the experimental tank.

Fish. Ten experiments were made, using one sea trout in each; the average length of these fish was $45 \mathrm{~cm}$., giving a population density of approximately I fish $/ 24 \mathrm{cu}$. $\mathrm{ft}$. $\left.\left(0.68 \mathrm{~m}^{3}\right)^{3}\right)$ water. Two experiments were done with 12 land-locked brown trout in each, giving a population density of I fish $/ 2 \mathrm{cu} . \mathrm{ft}$. $\left(0.05 \mathrm{~m} .^{3}\right)$ water; these fish ranged in size 
from Io to $23 \mathrm{~cm}$. in length. The experimental fish were adapted to brackish water before the beginning of each experiment by introducing sea water at the rate of approximately 4 gallons/hr into the lower tank.

Once the required degree of salinity minimum $2.5 \%(\mathrm{w} / \mathrm{w})$ was attained (Harvey, 1960) the sea-water supply was regulated to a slightly slower rate for the beginning of the experiment, the flow being such that aeration was required.

The experiments. The sequence for each experiment was to inject intramuscularly six brown trout (IO-I $3 \mathrm{~cm}$. long) with $0.25 \mathrm{ml}$. of a suspension of Aeromonas salmonicida. Strain 5 of A. salmonicida was used for Expts. I-5 and Expt. I I, and strain 7 for Expts. 6-IO and Expt. I2. The inoculated fish developed a well-defined 'boil' at the site of injection and died within 4-5 days, after which they were introduced into the sea-water tank containing the experimental sea trout or brown trout already adapted to the requisite degree of salinity. Sea trout and brown trout kept in a hatchery race-way during each experiment served as controls. At the conclusion of each experiment the sea-water tank was emptied and sterilized with hypochlorite solution, and thoroughly rinsed by pumping well-water through for $\mathrm{I} \mathrm{hr}$, the water then being tested to ensure that no residual chlorine remained (Windle Taylor, I958). During the experimental period a regular check was kept on water temperature, degree of salinity and dissolved oxygen content of the water. As each experimental fish died, it, together with the control fish, was examined for external lesions indicative of disease. Heart blood, kidney, liver, spleen, intestine and reproductive organs were examined for the presence of $A$. salmonicida.

\section{RESULTS}

The pathogenicity of Aeromonas salmonicida for sea trout and brown trout was successfully demonstrated in sea and brackish waters (Tables I, 2). Infection was transmitted at salinity values from $2.54 \%$ to $3.3 \mathrm{I} \%(\mathrm{w} / \mathrm{w})$ at water temperatures ranging from $5.6^{\circ}$ to $14.5^{\circ}$. While the strains of $A$. salmonicida used appeared to be identical, some variation occurred in the infectivity rate. Strain 5 of A. salmonicida was transmitted and caused the subsequent deaths of all of the sea trout and Io of 12 brown trout. Aeromonas salmonicida strain 7, however, infected and caused the deaths of only 3 of 5 sea trout and 7 of 12 brown trout.

The sea trout died within 7 days of contact with the infected fish. They did not develop 'boil-like' lesions, but superficial lesions were noted at the base of the pelvic fins, occasionally at the base of the pectoral fins, and around the vent; a brownish discharge from the vent was observed in several of the fish. The pathological picture in the sea trout was typical of the disease, most of the fish having developed congestion and haemorrhages in the internal organs, frequently with necrosis of kidney and spleen. Haemorrhages in the reproductive organs were common and in most cases the intestine was grossly congested. Aeromonas salmonicida was not recovered from control sea trout. It is interesting to note that one of the sea trout died within a few hours of being put into the experimental tank. This fish was found to be harbouring $A$. salmonicida which was recovered from kidney and heart blood; it is improbable that it had acquired the organism on re-entry to fresh water, since the fish had been removed from the river immediately on leaving tidal water, and had then been confined in well-water until required for experimental purposes.

Brown trout appeared to be more resistant than sea trout, remaining alive for up to 
I4 days after contact with infected fish. Again, 'boil-like' lesions were absent, but superficial lesions were noted at the base of the pelvic fins, occasionally at the base of the pectoral fins and around the vent. No brownish discharge from the vent was observed with any of these fish. The disease in brown trout was atypical in that there were few internal lesions; those lesions which did occur were found in the hind gut, reproductive organs and kidney. All control fish appeared to be healthy and did not yield Aeromonas salmonicida.

Table I. Infection of sea trout in sea water by contact with brown trout previously infected with Aeromonas salmonicida strain 5 (Expts. I-5) and strain 7 (Expts. 6-10)

\begin{tabular}{|c|c|c|c|c|c|c|c|}
\hline \multirow[b]{2}{*}{$\begin{array}{l}\text { Salinity } \\
(\%)\end{array}$} & \multirow[b]{2}{*}{$\begin{array}{l}\text { Average } \\
\text { water } \\
\text { temp. }\left({ }^{\circ} \mathrm{C}\right)\end{array}$} & \multirow[b]{2}{*}{ Sex } & \multicolumn{2}{|c|}{ Sea trout } & \multirow{2}{*}{$\begin{array}{l}\text { Time in } \\
\text { days } \\
\text { between } \\
\text { contact } \\
\text { and } \\
\text { death }\end{array}$} & \multirow[b]{2}{*}{$\begin{array}{l}\text { Isolate } \\
\text { result }\end{array}$} & \multirow[b]{2}{*}{$\begin{array}{l}\text { Site of } \\
\text { isolation }\end{array}$} \\
\hline & & & $\begin{array}{r}\text { Length } \\
(\mathrm{cm} .)\end{array}$ & $\begin{array}{l}\text { Weight } \\
\text { (g.) }\end{array}$ & & & \\
\hline \multicolumn{8}{|c|}{ Experiments I-5 } \\
\hline $3 \cdot 01$ & $14 \cdot 0$ & Male & 48 & 1049 & 7 & + & $\begin{array}{l}\text { Heart, liver, kidneys, } \\
\text { intestines, spleen, milt }\end{array}$ \\
\hline $2 \cdot 82$ & $14 \cdot 5$ & Male & 51 & 1467 & 7 & + & $\begin{array}{l}\text { Heart, liver, spleen, } \\
\text { kidneys, milt }\end{array}$ \\
\hline $2 \cdot 72$ & 13.5 & Female & $4 \mathrm{I}$ & 624 & $7 \frac{1}{2}$ & + & $\begin{array}{l}\text { Heart, liver, kidneys, } \\
\text { spleen, muscle }\end{array}$ \\
\hline $2 \cdot 54$ & $13 \cdot 0$ & Male & 43 & 829 & 6 & + & $\begin{array}{l}\text { Heart, liver, kidneys, } \\
\text { spleen, intestine, } \\
\text { muscle and testes }\end{array}$ \\
\hline $2 \cdot 63$ & II $\cdot 0$ & Female & 42 & 780 & 7 & + & Kidneys only \\
\hline \multicolumn{8}{|c|}{ Experiments 6-Io } \\
\hline $2 \cdot 96$ & $9 \cdot 0$ & Male & 45 & 985 & 7 & + & $\begin{array}{l}\text { Heart, liver, spleen, } \\
\text { kidneys, intestines, } \\
\text { muscle and testes }\end{array}$ \\
\hline $2 \cdot 90$ & $9 \cdot 6$ & Female & 43 & 794 & 5 & - & All organs negative \\
\hline $3 \cdot 3 \mathrm{I}$ & $8 \cdot 3$ & Female & 50 & 1417 & 7 & + & Kidneys only \\
\hline $0 \cdot 16$ & $5 \cdot 6$ & Female & 40 & 567 & 5 hours & + & $\begin{array}{l}\text { Kidneys, heart, } \\
\text { 'Carrier'? }\end{array}$ \\
\hline $2 \cdot 79$ & $8 \cdot 3$ & Female & 42 & 673 & 6 days & - & All organs negative \\
\hline
\end{tabular}

Death following infection acquired by injection of Aeromonas salmonicida suspension was more rapid for brown trout in fresh water than death following infection acquired by contact with infected fish in sea water. Injected fish died within 5 days; A. salmonicida was recovered from the heart blood and all other organs except the reproductive organs, and was also isolated from the skin lesions, together with Saprolegnia ferax which appeared as a secondary infection in the 'boil' tissue. One interesting observation recorded for all the injected brown trout was that when they were allowed to remain in fresh water the boil tissues remained ragged, deep red, and intact, whereas, in sea water the lesions became clear-cut and their contents were washed away, leaving undamaged muscle tissue. Davis (1946) reported that this type of lesion is typical of Ulcer Disease. 
Table 2. Experiments II and I2: infection of brown trout in sea water by contact with brown trout previously infected with Aeromonas salmonicida

\begin{tabular}{|c|c|c|c|c|c|}
\hline \multicolumn{3}{|c|}{ Brown Trout } & \multirow{2}{*}{$\begin{array}{l}\text { Time in days } \\
\text { between contact } \\
\text { and death }\end{array}$} & \multirow[b]{2}{*}{$\begin{array}{l}\text { Isolate } \\
\text { result }\end{array}$} & \multirow[b]{2}{*}{ Site of isolation } \\
\hline Sex & $\begin{array}{l}\text { Length } \\
\text { (cm.) }\end{array}$ & $\begin{array}{l}\text { Weight } \\
\text { (g.) }\end{array}$ & & & \\
\hline \multicolumn{6}{|c|}{$\begin{array}{l}\text { Experiment I I : infection with } A \text {. salmonicida strain } 5 \text {; } \\
\text { water temperature } 6.0^{\circ} ; \text { salinity } 3.01 \%\end{array}$} \\
\hline Female & 17 & 50 & 10 & + & Heart, liver, kidneys, ovary \\
\hline Male & 23 & 99 & IO & + & Heart, kidneys, testis, intestine \\
\hline Male & I9 & 71 & I I & + & $\begin{array}{l}\text { Heart, liver, kidneys, spleen, } \\
\text { testis }\end{array}$ \\
\hline Female & 14 & 28 & 12 & + & Heart, kidneys \\
\hline Male & 18 & 71 & 12 & + & $\begin{array}{l}\text { Heart, liver, kidneys, testis, } \\
\text { intestine }\end{array}$ \\
\hline Female & 18 & 57 & I3 & + & $\begin{array}{l}\text { Heart, liver, kidneys, spleen, } \\
\text { ovary }\end{array}$ \\
\hline Female & 10 & 14 & 13 & + & Kidneys \\
\hline Female & 18 & 64 & 13 & + & Heart, kidneys, intestine \\
\hline Male & 19 & 64 & 13 & + & $\begin{array}{l}\text { Heart, liver, spleen, kidneys, } \\
\text { testis }\end{array}$ \\
\hline Male & I5 & 28 & I4 & + & Heart, kidneys \\
\hline Female & 17 & 64 & Fish killed* & - & All organs negative \\
\hline Female & 15 & 28 & Fish killed* & - & All organs negative \\
\hline
\end{tabular}

Experiment 12: infection with $A$. salmonicida strain 7; water temperature $5 \cdot 6^{\circ}$; salinity $2 \cdot 99 \%$

\begin{tabular}{|c|c|c|c|c|c|}
\hline Male & 24 & 120 & 7 & + & $\begin{array}{l}\text { Heart, liver, spleen, kidneys, } \\
\text { testis }\end{array}$ \\
\hline Male & I I & 7 & 7 & + & $\begin{array}{l}\text { Heart, liver, spleen, kidneys, } \\
\text { testis, intestine }\end{array}$ \\
\hline Female & 20 & 57 & 7 & + & $\begin{array}{l}\text { Heart, liver, spleen, kidneys, } \\
\text { ovary }\end{array}$ \\
\hline Male & 19 & 85 & 9 & + & Heart, kidneys, intestine \\
\hline Male & 20 & 85 & 9 & + & Heart, kidneys, testis, intestine \\
\hline Female & 15 & 28 & I I & + & Kidneys \\
\hline Female & 20 & 78 & 13 & + & Heart, kidneys, ovary \\
\hline Female & I 7 & 50 & 14 & - & All organs negative \\
\hline Male & 19 & 64 & Fish killed* & - & All organs negative \\
\hline Female & 19 & 64 & Fish killed* & - & All organs negative \\
\hline Male & I 8 & $7 \mathrm{I}$ & Fish killed* & - & All organs negative \\
\hline Male & IO & 7 & Fish killed* & - & All organs negative \\
\hline
\end{tabular}

$+=A$. salmonicida isolated. $\quad-=A$. salmonicida not recovered.

* Fish killed denotes those fish remaining alive after 18 days, killed for bacteriological examination.

\section{DISCUSSION}

The main purpose of this work was to examine the pathogenicity of Aeromonas salmonicida for sea trout and brown trout in sea and brackish waters. Preliminary work had indicated that the longevity of $A$. salmonicida was similar in fresh water, brackish water and sea water; Smith (1962) reported that the viability of the organism in sea water is not negligible. Consequently it was necessary to consider the possibility of infection occurring in other than fresh water.

The experiments indicated that infection by contact with infected fish is possible in sea and brackish waters. Transmission of infection was studied at salinity values of 
$2 \cdot 54-3.3 \mathrm{I} \%$, simulating the salt content of estuarial waters and coastal sea waters, respectively. It appeared that infection by contact in these waters produced a generalized type of infection without localized skin lesions. Sea trout appeared to be more susceptible to this type of infection than did brown trout. However, environmental changes may have accounted for a weakening of resistance to infection. The sea trout had already been subjected to one complete change in osmotic pressure having been removed for experimental purposes from the river immediately on their re-entry to fresh water. Mackie et al. (1930) reported that on entering a river in which the disease existed fish became rapidly infected because of environmental changes. Although adequate concentrations of dissolved oxygen were maintained, it may be that in the experiments reported here water temperatures played an important part, being considerably higher during the experiments with sea trout than those with brown trout. Mackie et al. (1935) recorded the optimum temperature for the development of the disease as $13-19^{\circ}$, but when fish are weakened disease may occur at a considerably lower temperature, e.g. $7-10^{\circ}$ and, exceptionally, at or below $4^{\circ}$. They reported that oxygen deficiency was not one of the determining factors in the incidence of the disease.

It is difficult to compare the present results with those of previous work, because no reference has been found about the pathogenicity of Aeromonas salmonicida in brackish water or sea water. The implications of the present findings, however, could be interesting because Smith (I962) reported the possibility of furunculosis in salmon smolts. Her findings are fully supported by the results of preliminary work for this present investigation when $1 \cdot 7 \%$ of migrating smolts taken from the River Coquet during one season were found to be harbouring $A$. salmonicida. Furthermore, field observations by Mr J. T. Percival in 1964 (personal communication) suggested there was little evidence that salmon and sea trout which entered the River Coquet contracted furunculosis after entering fresh water. Percival observed only a small incidence of furunculosis in the River Coquet during the years I946-57. However, after the removal of the commercial net in the estuary in 1958 , Percival observed an alarming increase of migratory fish dying from the disease the following season. As Percival pointed out, it is impossible for sick fish to fall back into tidal areas from fresh water in the Coquet because they are obstructed by a dam and fish pass which define the tidal limit. Hence these sick fish may have been returning migrants harbouring the organism which had survived a period in the sea or had become infected in the tidal water. The present findings contradict the concept that furunculosis is only transmitted in fresh water. It would also appear that migratory fish might play an important role both in transmitting the infection and as reservoirs of the disease.

The author wishes to thank Superintendent J. T. Percival for information and discussion, to express appreciation to the Northumbrian River Authority for permission to publish this work, and for the assistance and experimental facilities provided by the Fisheries Department of the Northumbrian River Authority. 


\section{REFERENCES}

Davis, H. S. (1946). Care and diseases of trout. Res. Rep. U.S. Fish Wildl. Serv. 12, 98.

Harvey, H. W. (1960). The Chemistry and Fertility of Sea Waters, and ed. Cambridge University Press.

JONES, J. W. (1959). The Salmon. London: Collins.

Mackie, T. J., Arkwright, J. A., Pryce-Tannatt, T. E., Mottram, J. C., Johnston, W. D. \& Menzies, W. J. (1930). Interim Report of the Furunculosis Committee Edinburgh. H.M.S.O.

Mackie, T. J., Arkwright, J. A., Pryce-Tannatt, T. E., Mottram, J. C., Johnston, W. D. \& MenzIes, W. J. (1933). Interim Report of the Furunculosis Committee Edinburgh. H.M.S.O.

Mackie, T. J., Arkwright, J. A., Pryce-Tannatt, T. E., Mottram, J. C., Johnston, W. D. \& Menzies, W. J. (1935). Final Report of the Furunculosis Committee Edinburgh. H.M.S.O.

Mackie and McCartney's Handbook of Bacteriology (1960). Ioth ed. Ed. by R. Cruickshank. Edinburgh and London: E. S. Livingstone Ltd.

McCraw, B. M. (1952). Furunculosis of fish. Spec. scient. Rep. U.S. Fish Wildl. Serv. (Fisheries), No. 84.

Sмiтн, I. W. (1962). Furunculosis in kelts. Freshwat. Salm. Fish. Res. 27.

WiNDLE TAYLOR, E. (1958). In The Examination of Waters and Water Supplies, 7th ed. Ed. by Thresh, Beale and Suckling. London: J. and A. Churchill Ltd. 
